\title{
Ergonomics issues in conceiving an accessible project
}

\author{
Costa. A. L. ${ }^{\text {a }}$ Coura. P.V. ${ }^{\text {a }}$, Gomes. M. M. A. ${ }^{\text {a }}$, Peregrino. Y. R. ${ }^{\text {a }}$, Sarmento. B. R ${ }^{\text {a }}$ and Sousa. R. A. ${ }^{a}$ \\ ${ }^{a}$ Department of Architectura, Federal University of Paraiba, Campus I. Cidade Universitária, João Pessoa, PB, \\ Brasil,CEP 58051-900
}

\begin{abstract}
Public space is endowed with undeniable social relevance, thus becoming a defining element of integration and interaction among its users. Aware of this importance the Universidade Federal da Paraíba (UFPB), linked to the Ministério da Educação e Cultura (MEC), develops the project "UFPB para todos: eliminando barreiras" (UFPB for all: removing barriers) that aims to conceive an architectural design of an accessible rout to UFPB's campus I, and execute a pilot stretch of this route. This article aims to subsidize the preprojectual phase by understanding the needs of this campus' users, through the concepts of ergonomics and universal design. Was performed out direct observation of the space, and the methods of interviews and observation of user behavior were applied to a group of students with disabilities, through the techniques of assisted walking, photographic and video recording. Based on those, projective guidelines have been defined, which will contribute to the final project's quality, so that this is not a simple application of the rule, but works free of segregating barriers.
\end{abstract}

Keywords: architectural project, accessible rout, ergonomics, universal design, users needs

\section{Introduction}

Currently, the architectural and urban planning have increasingly focused on the user's needs, seeking on ergonomics, manners to achieve their needs maximizing comfort. As recommended by Iida [9]:

Ergonomic is defined as the adaptation (emphasis added by the author) of work to men. The work here has a very wide connotation... Covering planning and designing activities that occur before (emphasis added by the author) the work has been done, and those activities of control and evaluation, which occur during (emphasis added by the author) and after (emphasis added by the author) this work. All this is necessary so that work can achieve the desired results.

Mace [4] complements when formulates the concept of universal design, as the project developed, not to meet a specific need, or an individual, but to satisfy all possible users.

Is precisely this closer relationship with users' needs, established within the ergonomics studies, and deepened by the concept of universal design, which is intended to be applied in the present work, seeking on meeting the needs and desires of users, the key to solve the project, so this paper does not intend to introduce new anthropometry parameters, or questioning the current ones, but to discuss the specific case of UFPB's pilot route, trying to understand which are the major difficulties of the different users of this space, and how they experience the space, playing on it the most varied activities. And, starting from this information, reach a solution that addresses the problem.

However, designing these proposals is not a simple task, especially when working with the public space where, according to Cambiaghi [3], the heterogeneity of the physical limitations of users is a major difficulty in the removal of physical barriers; (Brazil [2]) defines a physical barrier as physical elements, manufactured or natural, existing on external and internal

*Corresponding author: pedrovcoura@hotmail.com 
spaces, public or private buildings, in urban spaces and on transportation systems.

Another difficulty arises from the fact that the project consists in intervening in an already urbanized area, and constitutes in a proposal for adaptation of a public space, talking about the projects of adaptation Iida [9] judges them as far from an ideal situation, which, he says, would be a project where the principles of ergonomics are added to the environment, product, or machine, since the moment of conception, allowing a comprehensive assessment of the alternatives. However, the same author, considers that interventions cases creates the possibility of making decisions based on real situations and concrete data, what enriches the process.

Taking as the first difficulty the diversity of issues to be solved in the project, was taken as the direction what says the European Concept for Accessibility (ACE, [7]) when dealing with human capabilities and limitations, must be addressed considering the diversities dimensional, perceptual, motor and cognitive skills. This definition provides a more direct line to observe the problem that, initially, presents itself very complex.

In Brazil, people with disabilities does not have cities to suit their needs, and a simple difference of sidewalk may already represent an insurmountable barrier for many (Yazigi, [12]). Several other obstacles are also mentioned: the precarious maintenance of sidewalks, presence of debris and cars on the sidewalks, the lack of information or inadequate information, including Braille, etc.

Mont'Alvão [10] proposes that the constructed environment should provide comfort, safety and equality in its use, and should provide clear and accurate information, but for this practice permanent and directed actions are necessary, so that develops accessible projects that meet all citizens, whatever their limitations or restrictions are.

It is in this context that the UFPB Campus I is evidenced, located in the district Castelo Branco, João Pessoa - PB - Brazil. Created in 1960, the Campus has a total area of 180 ha, distributed in 09 teaching centers, in addition to areas of experience (Center of Experience, University Restaurant, University residency, ecumenical temple, courtyards), administrative sectors (Rectory, University Prefecture, Departments, Coordination), service sectors (university hospital, daycare, banks, libraries, cafeterias, photocopying) and the sports sector (Soccer field, sports facilities, gymnasiums, swimming pools), with large builtup areas and a large Atlantic Forest preserved area, Figure 01.

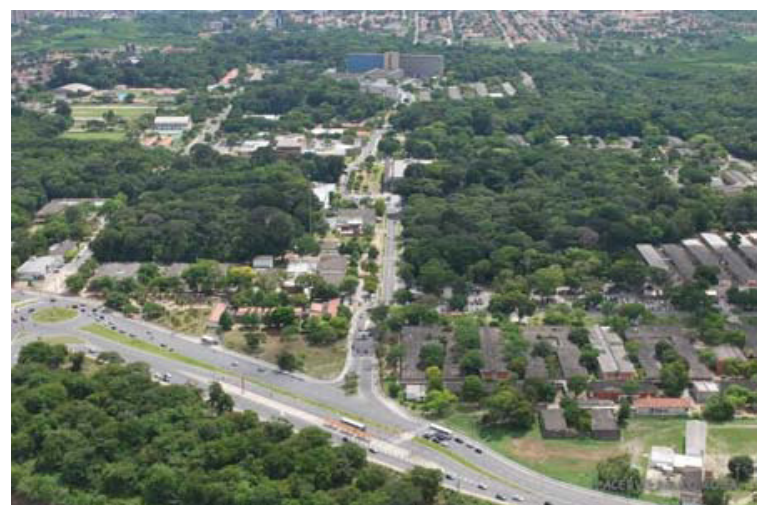

Fig.1. Aerial photograph of the Campus I. Source: http://www.skyscrapercity.com/showthread.php?t=111

In 2010, the Board of Education, and Extension Reserch (CONSEPE) UFPB [11] decided to reserve $25 \%$ of vacancies to quotas (which includes social and ethno racial divisions). From the 2011 selection process, the same institution, within this percentage, reserved $5 \%$ of vacancies for people with disabilities (UFPB, [11]. In face of this fact, the university needs to prepare adequately to receive these people, which makes it essential that their spaces are designed and / or adapted committed to accessibility. One of the actions in this regard is the project "UFPB for all: removing barriers" COSTA [5], which has as main objective to promote accessibility on campus, through the design of an architectural project of an external accessible route for the UFPB Campus I, and the implementation of a pilot section of this route.

Accessible route is a continuous path, unobstructed and signaled that connects the external or internal environments of spaces and buildings, and can be used autonomously and safely for all people, including those with disabilities. External Accessible Route can incorporate parking lots, lowered pavements, pedestrian crosswalk, ramps and signage both horizontal and vertical (ABNT, 2004).

However, to propose an accessible route to the UFPB campus I, the project ran into complications inherent in his nature. And at the stage of preliminary studies two issues were raised: the detailed knowledge of the area's physical arrangement, which is necessary, because it is an intervention in an already urbanized area, which seeks a better use and integration with the existing elements in the intervention area; and the survey of users' needs, therefore, any projectual solution must be based on this information, in order to propose projects that keep the focus on the users to provide a comfortable way to carry out the activities involved on the system, since the work must be suitable to man, and not vice versa, as can be seen by the definition of ergonomics adopted by the International Ergonomics Association (IEA) [8]: 
Ergonomics (or human factors) is the scientific discipline concerned with the understanding of the interactions among humans and other elements of a system, and the profession that applies theoretical principles, data and methods to design in order to optimize human well being and overall systems performance.

Practitioners of ergonomics, ergonomists, contribute to the planning, design and evaluation of tasks, jobs, products, organizations, environments and systems in order to make them compatible with the need, abilities and limitations of people.

This article is the results obtained in studies developed to answer such questions.

\section{Methodology}

First, the urban space between the Central Library, the University Restaurant (UR) and the Center for Experience (CE) was elected as the study area, for its vitality, and strategic location (linking various centers) as well as the importance of services offered there, which will benefit all UFPB's users, figure 2.

on NBR 9050/04 [1], aided by photographic and mapping the physical layout.

Defined the criteria to chose the path, and made this choice, which can be verified by the route marked in blue in Figure 2. The chosen route was evaluated by a group of 03 users with different disabilities, through the method of assisted walking created by Dischinger [6]. This technique consists in a form of reading and understanding the space, in which there is integration between researcher and user, which assess the conditions of the physical space perceived by the user in real situations.

For the study, were invited three UFPB students with different disabilities: reduced mobility, subnormal vision and total loss of vision; which walked through the path elected as the pilot rout without any help (interference) of the researchers, reporting their difficulties and feelings.

\section{Data analysis}

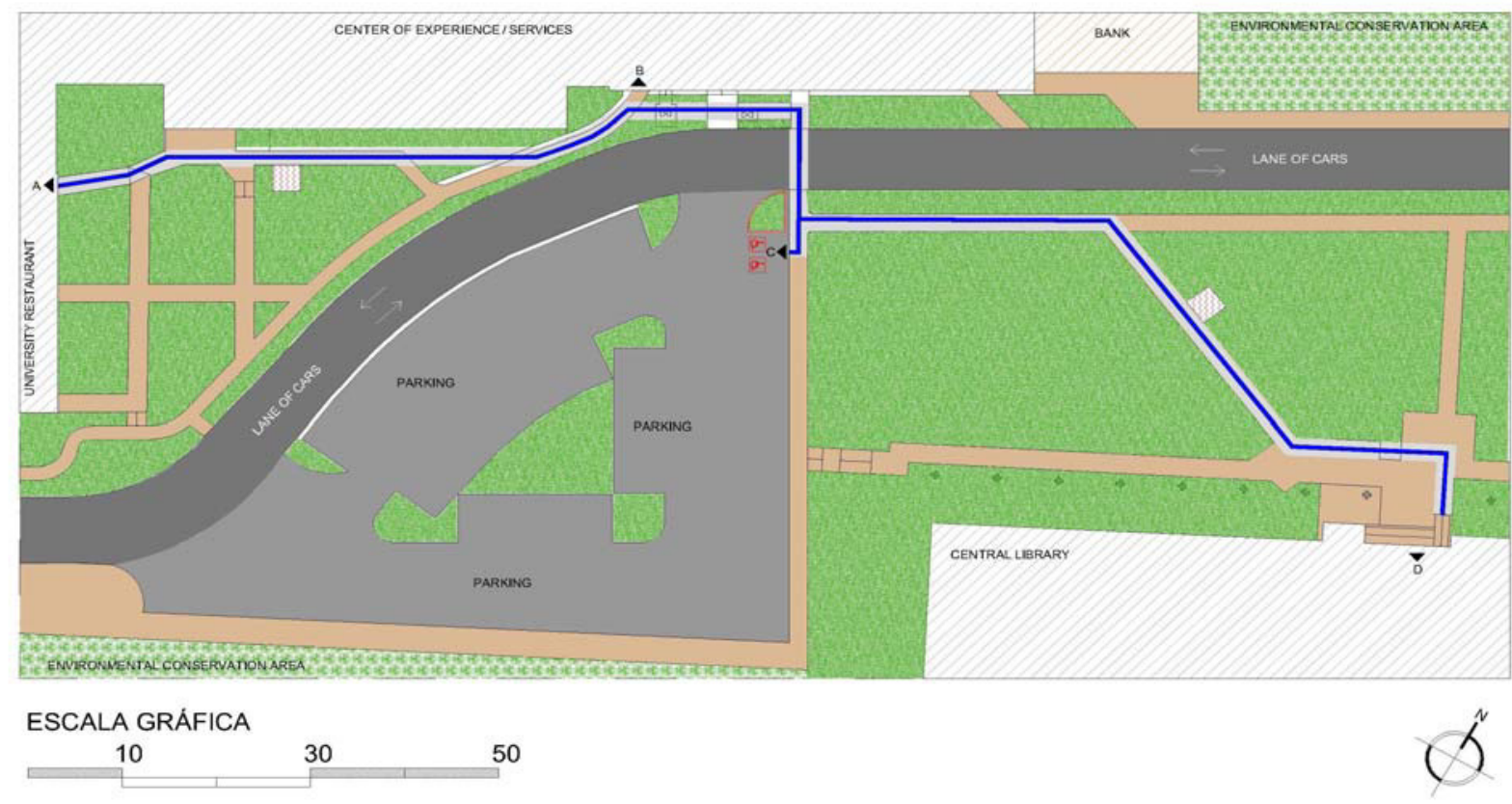

Fig.2. Layout of the physical arrangement, resultant of the architectural survey.

Through direct observation it was noticed that there are numerous possibilities of routes (paths) to access the buildings. The third step was to check the physical condition of these paths through architectural survey, analysis and evaluation with a script based
The survey of the physical arrangement revealed numerous inadequacies to the NBR-9050/2004, in addition to problems of maintenance of the sidewalk's structure, the architectural survey also revealed that the architectural plans provided by the University Prefecture was disconnected and incorrect, and the 
nonexistence of a cartographic survey. these findings become great difficulties, since the researchers had to collect all the information in the field, and this process delayed the project.

Direct observations revealed numerous possibilities to access the buildings through the existing sidewalks in the area, and determined which are in better condition and that are actually used by the general population.

\subsection{The chosen route}

With all of the information provided by the architectural survey, it was possible to choose which of the existing routes would be used, figure 2 , for such were taken as guidelines: the better use of the existing sidewalks, in order to save resources, time and labor, the route that allows accesses to the three mentioned buildings and the parking lot, where there will be reserved special vacancies, and the section that provides greater comfort for users, enabling more shading and fewer changes in direction. These latter criteria have to do with the hot and humid climate of the region that requires shading to improve the thermal comfort, and ease of spatial orientation respectively.

\subsection{Technical evaluation}

Following the specifications of the NBR 9050 (ABNT, 2004) have observed:

- Dimensions of the sidewalk: the minimum width found in the stretch was $1.5 \mathrm{~m}$, being within the minimum acceptable parameters;

- Inclination: all the inclined rides have longitudinal gradients according to the rules, although these inclinations should also be checked by a topographic survey to be held by the institution, because the research did not have adequate facilities to conduct an accurate survey . And regarding the ramps, are all inclined less than $8.33 \%$, as required by the rule;

- Signalization: it was observed that there is no type of signaling, such as tactile floor, maps, identification of the vacancy on parking lot, indicating of accessible ramps, among other;

- Crossing the lane: was noted the existence of a ramp on one side of the lane, without the presence of an opposite ramp, and there is no crosswalk at the location where there is a ramp. There isn't, throughout the intervention area, the presence of a pedestrian crosswalk;

- Exclusive parking lot vacancies: does not exist;
- Urban furniture: the furniture is all about 03 bins, 04 public telephones, 02 seats and lampposts. None of these have any special treatment in terms of accessibility, nor are signaled.

\subsection{Technical evaluation}

\subsubsection{Assisted walk whit person with reduced mobility}

The student with reduced mobility walk by de institution with help of a handicapped walker, she says that already was user of wheel chair, way that she consider less tiring, but she prefer the walker by allows she more stand-alone and more flexibility to lead with the barriers.

The student pointed as one of the biggest problems of the rout, the floor condition of conservation, whereas any existing failure is a barrier that difficult your walk, because when she walks, she drags her feet on the floor. Other point to be emphasized was the need of an elevated crosswalk in the crossing of the lane, Figure 3.

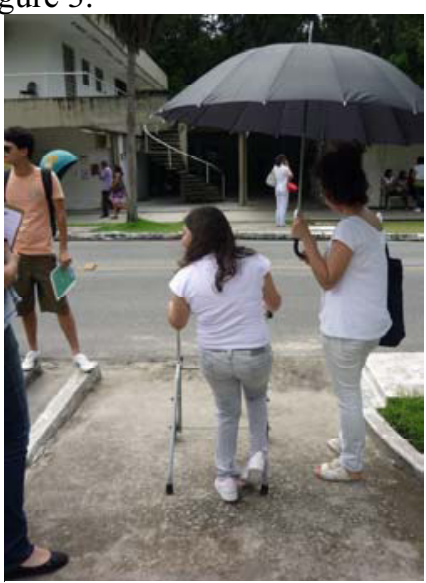

Fig.3. Photography of the assisted walk showing the lane without the crosswalk

Although the student don't call attention to the dimension of the sidewalks, was perceived that it is uncomfortable - in despite of it has $1.5 \mathrm{~m}$ of width, dimension that is correct according with the less established by the norm - NBR 9050/2004 (ABNT, 2004 ) - but to avoid to fall in the side of the sidewalk, the student has the need to transit in the middle of it, reducing the area to the others pedestrians that come in opposite way, Figure 4. 


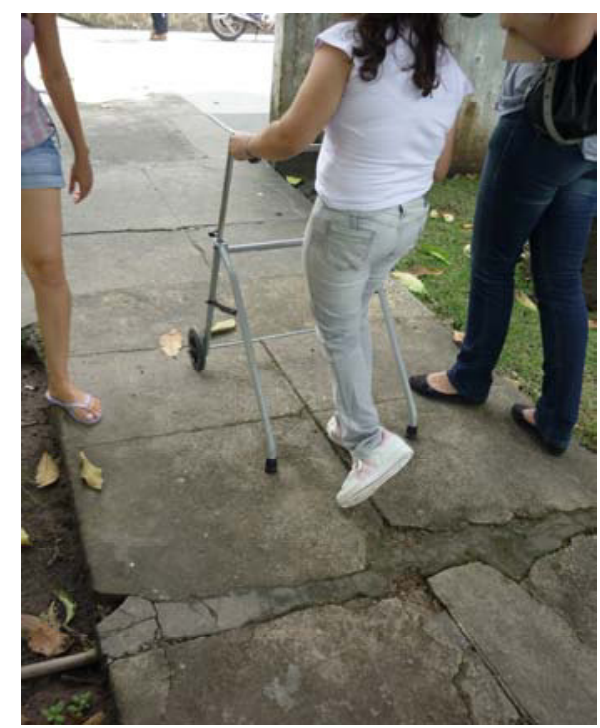

Fig.4. Photography showing a close of the sidewalk

\subsubsection{Assisted walk whit person with subnormal vision}

The student with subnormal vision, realized the course quickly and with less difficulties thatthe others. During the assisted walk, she indicated the lack of security, suggested the enlargement of the sidewalks and the reduction in the amount of the direction changes. When asked about the best colors to the tactile floor that would be applied in the route, the student reinforced the importance of the contrast clear-dark, emphasizing that the current floor is perceived as a clear background, then the tactile floor should be of a dark color, to generate a contrast more easily perceived.

\subsubsection{Assisted walk whit person with total loss of vision}

This student had more difficulties during the assisted walk due the lack of signaling focused to the people with visual disabilities, citing as main problems of the route the absence of the tactile floors and the tactile maps.

During the entire route, the student had difficulty to guide herself by the side of the sidewalks, because it doesn't show the mark guide and is border by grass, both are at the same level, and in some points it invades the sidewalk. Figure 5 .

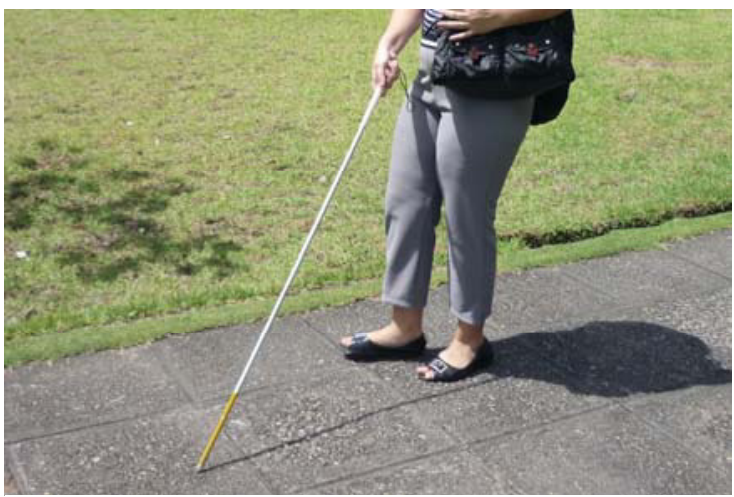

Fig.5. Photography of the student with total loss of vision walking in the route

The student related that she doesn't has much experience with tactile floor, because, in the Campus, it only exist in the bank agencies, fact that was a surprise to the researchers that waited She to had familiarity with the object.

When asked about the urban furniture, the user indicated that it is easier to her find it if it is concentrated in specific points through the route. The student suggested yet the installation of a sound alarm in the cross of the lane, although she assumes that drivers always stops so the pedestrian can cross the lane, but she related to have difficulty to know if the vehicles are stooped, and the alarm should give to her more security.

\section{Final considerations}

The set of methods and techniques used generated sufficient and necessary knowledge to the group about the reality of the studied site, emphasizing its shortcomings and potential; moreover, research with users has brought about their concerns, and confirmed what the literature says about their difficulties. The relevance of ergonomics in the design process was perceived by the group when noted the difficulty, for those who have limitations, in walking through the route. And adapt existing urban reality for these people, so that all users, regardless of their limitations, may have autonomy in this space, is a hard work of research, always seeking to discover the real needs of users, and generate solutions that attempt to everyone, so as to produce with, maximum efficiency, a route with full accessibility, and that it is not only accessible in accordance with the rules, but, to become a specific adaptation to this particular location, providing, in addiction to accessibility, what is proposed within the concepts of ergonomics, such as comfort, 
maximum efficiency of the produced object and constant security of its users.

As a result we propose the guidelines for the preparation of the pilot project of the route:

- The route must be comfortable, using a simple and efficient route that avoids dispending unnecessary effort, and along the route less changes of direction;

- Minimize displacement by choosing the shortest paths between buildings;

- Seek for spatial legibility;

- Take advantage of the physical structure of existing sidewalks in the path of the route, thus aiming to provide greater environmental sustainability and financial economics, since the interventions will be smaller in already structured paths;

With the accessible route is intended to provide, above all, greater mobility for users, and in that sense, is rethinking urban design in pre-existing route, adding appropriate signals and urban furniture, considering the principles of universal design and seeking to promote inclusion.

The route must be comfortable, using a simple and efficient route that avoids dspending unnecessary effort stress, and along the route less changes of direction

The development of this study elucidates several relevant issues to the projectual phase. However, it was the studies that have been made with the users who yielded the most interesting results, by making it possible to understand their expectations and needs, which, certainly, will be translated into a comfortable and safe design that will allow autonomy to all users.

\section{References}

[1] ABNT (Associação Brasileira de Normas Técnicas). NBR 9050 - Acessibilidade a edificações, mobiliário, espaços e equipamentos urbanos. Rio de Janeiro: ABNT, 2004.

[2] BRASIL. Brasil Acessível: Programa Brasileiro de Acessibilidade Urbana - Caderno 2: Construindo a cidade acessível. Secretaria Nacional de Transporte e da Mobilidade Urbana, Ministério das Cidades, Brasil: 2006a. Disponível em <http://www.cidades.gov.br/secretariasnacionais/transporte-e-

mobilidade/arquivos/Brasil\%20Acessivel\%20-

\%20Caderno\%202.pdf>. Acesso em: 02 abr. 2011.

[3] Cambiaghi, Silvana S.. Desenho Universal: métodos e técnicas para arquitetos e urbanistas. São Paulo: Editora SENAC, 2007.

[4] Connell, R. Bettye; Jones, Mike; Mace, Ron, Mueller, Jim; Mullick, Abir; OstroffS, Elaine; Sanford, Jon; Steinfeld, Ed; STORY Molly and VADERHEIDEN, Gregg. T. The Principles of Universal Design. The National Institute on Disa- bility and Rehabilitation Reserch, U.S. Department of Education. NC State University, The Center for Universal Design. 1997.

[5] Costa, Angelina D. L.. Projeto Incluir 2011. UFPB para todos: eliminando barreiras. Ministério da Educação. Secretaria de Educação Superior. UFPB. João Pessoa. 2010. Disponível em $<$

http://sigproj1.mec.gov.br/siex.php?id=7\&plataforma=1 \&acao=1>. Acesso em: 09 ago. 2010.

[6] Dischinger, Marta. Designing for all senses: accessible spaces for visually impaired citizens. Göteborg, Suécia, 2000. Department of Space and Process, School of Architecture, Chalmers University of Technology.

[7] ECA. European Concept for Accessibility: Manuel d'assistance technique 2003. Le Gouvernement du GrandDuché de Luxembourg. Ministère de la Famille et de I'Intégration. $2003 . \quad$ Disponível em<http://www.eca.lu/index.php?option=com_docman\&tas $\mathrm{k}=\mathrm{search}$ result\&Itemid $=26>$. Acesso em:28 jul.2011.

[8] International Ergonomics Association. Definition of Ergonomics. $2000 . \quad$ Disponível em $<$ http://www.iea.cc/01 what/What\%20is\%20Ergonomics.ht ml>. Acessado em: 09 ago. 2011.

[9] Iida, Itiro. Ergonomia - Projeto e Produção. São Paulo: Ed. Edgard Blucher Ltda, 2005.

[10] Mont'Alvão, Cláudia. Acessibilidade no ambiente construído carioca. In: $7^{\circ}$ Congresso Brasileiro de Pesquisa e Desenvolvimento em Design, Paraná. Anais. Paraná: 2006. Disponível em $<$ http://wwwusers.rdc.pucrio.br/cmontalvao/montalvaochellesPeD06.pdf $>$. Acesso em: 28 mai. 2010

[11] UFPB, Agência de notícias - Pólo multimídia. UFPB adota sistema de cotas. João Pessoa, 30 mar. 2010. Disponível em:

http://www.agencia.ufpb.br/vernoticias.php?pk_noticia=116 40>. Acesso em: 24 de mai. de 2010.

[12] Yázigi, Eduardo. O mundo das calçadas: por uma política democrática dos espaços públicos. São Paulo: Humanitas/ FFLCH/ USP; Imprensa Oficial do Estado, 2000. $548 \mathrm{p}$. 